This is an Author's Original Manuscript of an article submitted for consideration in Nationalities Papers (৫ Taylor \& Francis);

Nationalities Papers is available online at http://www.tandfonline.com/toc/cnap20/current\#.UkLdT1M9860

\title{
Identity and Alignment in Central Eurasia
}

\section{S. Neil MacFarlane ${ }^{1}$}

There are associations between powers that seem to be deeper than formal alliances, to be based on affinity and tradition as much as interest, to be not so much utilitarian as natural. (Martin Wight) ${ }^{2}$

Therefore I say that it is a narrow policy to suppose that this country or that is to be marked out as the eternal ally or the perpetual enemy ... Our interests are eternal and perpetual and those interests it is our duty to follow. (Lord Palmerston) ${ }^{3}$

\section{Introduction}

This chapter examines alliance behaviour in Central Eurasia (the eight Central Asian and Caucasian republics of the former Soviet Union), focusing on identity as a factor determining state alignment (used interchangeably with alliance) choice. Identity is only one possible determinant of these choices. As discussed further below, others include the distribution of power, ideology, regime type, and economic gain. To what extent does identity shed light on alignment choices that are not fully explained by these other factors? To what extent are these various factors mutually constituted, or, to put it in plain English, to what extent have identity issues affected these other variables and vice versa?

I take alignment to mean "a formal or informal arrangement for security cooperation between two or more sovereign states." ${ }^{4}$ Identity can be defined by its content: "constitutive norms, social purposes, relational comparisons with other social categories, and cognitive models." This content generally involves a set of customs and practices that distinguish a group from other groups. The focus of identity may be ethnic and cultural, religious, or common historical experience. ${ }^{6}$ These characteristics may be weakly or strongly held.

The concept of identity is complex for several reasons. One is that, although frequently rooted in deep cultural and historical attributes, it is contested ${ }^{7}$ and fluid. People and states can define their identities in different ways in different contexts and at different times. Identity both affects and is affected by a dynamically changing environment. ${ }^{8}$ For example, in a number of the examples covered in this chapter, identity appears to be a driver of conflict (and therefore of alignment behavior). But the experience of conflict in turn may affect the construction and reconstruction of identity. It is also plausible that the experience of stable alignment may influence the content of national identity.

Moreover, personal or group identity is multifaceted. As Eric Hobsbawm once put it, people do not choose "collective identification as they would [choose] shoes, knowing that one could only put on one pair at a time." ${ }^{\prime 9}$ Where state identity appears weak, one reason may be that other identities with which it cohabits are stronger. 
This is an Author's Original Manuscript of an article submitted for consideration in Nationalities Papers (৫ Taylor \& Francis); Nationalities Papers is available online at http://www.tandfonline.com/toc/cnap20/current\#.UkLdT1M9860

Finally, identity may be deliberately produced through elite messaging. Governing (or for that matter opposition) elites may project particular versions of identity for their own political or economic purposes. ${ }^{10}$ Identity may be imposed from above rather than emerging from below. As such, the concept is difficult to operationalize.

The focus in this chapter is on the influence of state identities on alignment. That is because the issue of alignment is generally seen in the literature to be a matter between states. This may simplify the problem of operationalization. However, it should be recognized that non-state actors (e.g. social and religious movements, ethnic minorities, criminal groups) may have conceptualizations of identity that do not coincide with state territoriality and identity construction. State or regime identity narratives may conflict with substate (local, regional) or transnational narratives. The hegemony of the statist narrative is by no means assured. This issue is revisited at various points in the analysis that follows.

In the abstract, identity can be a driver (motivator) of alliance decisions in at least two ways. First, identity may directly determine alliance choice. In this version, a state seeks alliances because it believes there is an affinity between itself and the target of its affection. The reverse is also the case; antipathies rooted in perceptions of identity may cause a state to avoid alignments with other states that might make sense on power-political grounds.

Second, the effect of identity may be indirect. Identity, or its perception by others, may play a significant role in generating security dilemmas or threats for states. In this respect, identity helps constitute the power-political challenges to which states respond in their alliance behaviour.

Identity can also be an instrument of state policy. Here, identity claims are a means to secure association with another state in order to solve problems that are the product of other variables, rather than being a cause of the quest for association. That is, correlation does not imply causation; in such instances, affinity does not motivate the alignment decision. ${ }^{11}$

Until 1991, the countries of Central Eurasia had no modern history of sovereign statehood. When faced suddenly, and for many to their surprise and discontent, with independence and the need to develop their own foreign and security policies, they had no experience of international alignment and probably had not thought very much about it at all.

They also faced a number of security threats. Some were internal, reflecting economic meltdown and sudden massive poverty, collapsed state structures, weak national cohesion and ethnic and religious tensions. Others involved emerging rivalries with neighbours. All states in the region faced potential risks from neighbouring great powers, not least Russia, but also Iran, Turkey, and China. None of these neighbours had established policies towards the region discussed here. The same was true of major players in the larger international system, such as the US and the European states. 
This is an Author's Original Manuscript of an article submitted for consideration in Nationalities Papers (৫ Taylor \& Francis); Nationalities Papers is available online at http://www.tandfonline.com/toc/cnap20/current\#.UkLdT1M9860

Since 1991, an extraordinary range of alignments have emerged. Armenia, Kazakhstan, Kyrgyzstan, Tajikistan joined Russia in the Tashkent Treaty in 1992 and its successor, the Collective Security Treaty Organization (CSTO), in 2002. Turkmenistan instead chose not to choose, proclaiming neutrality and refusing membership in security structures of any kind. Uzbekistan and Azerbaijan have sought to avoid too close an association either with Russia or with Western states and organizations, tilting back and forth as conditions change. Azerbaijan has also developed a reasonably deep security relationship with a neighbouring regional power, Turkey. Finally, a number of the region's states have been fitfully involved in regional security cooperation outside the CIS/CSTO framework. ${ }^{12}$

The alignments that do emerge in the region are sometimes quite unstable. Over the period in question, for example, Zviad Gamsakhurdia's Georgia rejected Russia. Under pressure from both Russia and from secessionist movements in Abkhazia and South Ossetia, Shevardnadze's Georgia joined the Commonwealth of Independent States (CIS) in 1993 and agreed, but never ratified, a long term basing arrangement for Russian forces. After the 2003 Rose Revolution, Saakashvili's Georgia turned dramatically away from Russia, seeking membership in NATO and the EU.

Alignment decisions involve not only the states of the region, but those whom they court (or who court them). Concerning neighbouring regional powers, Russia, somewhat unevenly but to an increasing degree, has sought to construct security arrangements with its "new" neighbours that ensure continuing Russian preponderance. ${ }^{13}$ Turkey has been sporadically active in seeking close relations with most of the states of Central Eurasia, Turkic or not. ${ }^{14}$ In contrast, China has shown little sustained interest in creating exclusive alignments with the states of the region, although it has increased its economic involvement in Central Asia to the point where it is now the major trading partner of most states there. Its limited engagement in the security affairs of the region has focused on the Shanghai Co-operation Organization (SCO). ${ }^{15}$ Iran has not been a significant player in the politics of alliance in Central Eurasia.

How did this happen? What explains these states' choice of partners? How useful is the identity variable in explaining state alignments in Central Eurasia?

It has been suggested that the extent to which identity matters in state alliance choice depends on the intensity and immediacy of threats. Where threats are not so compelling, identity plays a stronger role. ${ }^{16}$ In this chapter, I suggest that this pattern is not evident in Central Eurasia. Alliance relationships tend to be weak and unstable. Identity plays little direct role in alliance choice.

On the other hand, it does play an indirect role. There are numerous regional examples where identity influences state or regime definition of threat. This definition in turn plays a significant role in influencing alignment decisions. Alignment behavior in the region suggests a second role for identity in the region. On occasion, it has been used instrumentally to influence the decisions of potential alliance partners. 
This is an Author's Original Manuscript of an article submitted for consideration in Nationalities Papers (৫ Taylor \& Francis); Nationalities Papers is available online at http://www.tandfonline.com/toc/cnap20/current\#.UkLdT1M9860

I begin with a brief outline of various theoretical approaches to explaining alignment. The discussion then turns to an empirical discussion of alignment in the region. The paper concludes with an analysis of the role of identity in Central Eurasian alignment decisions.

\section{Explaining Alignment}

In this section, I examine the various theoretical approaches to the question of alignment. I begin with the realist explanation, and then consider Stephen Walt's adjustment of realism to focus on threats rather than power. The section proceeds to a brief discussion of economic (welfare), ideological, and domestic structural explanations for alignment before turning to identity as an explanation of alignment.

\section{Realist Approaches}

The conventional interpretation of state alignment is realist and rooted in the distribution of power. In the classical realist tradition, as Wight pointed out, it was "natural" for powers to develop sustained alignment with another power when both were faced by a durable threat from a third. ${ }^{17}$ The system therefore tended towards a stable balance of power. This view is systematized by structural realists such as Kenneth Waltz. The structural realist view is capacities-driven. States facing a rising power would balance against it through alliances with other states similarly threatened. Trends in the distribution of power account for alignment. ${ }^{18}$

If the distribution of power is the key to the alignment decisions of states, then it is worthwhile to describe that distribution in the Central Asian region. The resource and demographic endowments of the states of the region vary widely.

Table 1. Indicators of National Power in Central Eurasia

\begin{tabular}{|l|l|l|l|}
\hline & Population (2010) & $\begin{array}{l}\text { GDP (current US\$ - } \\
20010)^{20}\end{array}$ & $\begin{array}{l}\text { Military Expenditure } \\
(2010)^{21}\end{array}$ \\
\hline Armenia & $3.09 \mathrm{~m}$ & $9.37 \mathrm{bn}$ & $.404 \mathrm{bn}$ \\
\hline Azerbaijan & $9.05 \mathrm{~m}$ & $51.78 \mathrm{bn}$ & $1.421 \mathrm{bn}$ \\
\hline Georgia & $4.45 \mathrm{~m}$ & $11.67 \mathrm{bn}$ & $.452 \mathrm{bn}$ \\
\hline Kazakhstan & $16.3 \mathrm{~m}$ & $149.06 \mathrm{bn}$ & $1.227 \mathrm{bn}$ \\
\hline Kyrgyzstan & $5.37 \mathrm{~m}$ & $4.62 \mathrm{bn}$ & $.167 \mathrm{bn}(2009)$ \\
\hline Tajikistan & $6.88 \mathrm{~m}$ & $5.64 \mathrm{bn}$ & $.055 \mathrm{bn}(2004)$ \\
\hline Turkmenistan & $5.04 \mathrm{~m}$ & $20 \mathrm{bn}$ & $.233 \mathrm{bn}(1999)$ \\
\hline Uzbekistan & $28.16 \mathrm{~m}$ & $38.98 \mathrm{bn}$ & $.070 \mathrm{bn}(2003)$ \\
\hline
\end{tabular}


In Central Asia, Uzbekistan and Kazakhstan have endowments that far outstrip those of Kyrgyzstan, and Tajikistan. Turkmenistan, with a small population, but substantial reserves of natural gas, falls in between. In the Caucasus, Azerbaijan has a far larger population and energy endowment than does Armenia or Georgia. As Azerbaijani oil and gas has come on stream, the country's GDP has grown far more rapidly than that of its neighbours.

From a realist perspective, and looking at Central Eurasia in isolation, what kind of alignments might we expect? In Central Asia, the theory predicts that the smaller states would align with the weaker of the two large ones (Uzbekistan). ${ }^{22}$ In the Caucasus, we might expect Armenia and Georgia to balance against Azerbaijan. Neither has occurred.

One possible reason for this result is that the region cannot be considered in isolation. It is embedded in a larger Eurasian space and is surrounded by regional powers whose capacity is much greater than that of the local states.

Table 2. The Major contiguous States

\begin{tabular}{|l|l|l|l|}
\hline & Population (2010) & GDP (2010) & $\begin{array}{l}\text { Military Expenditure } \\
(2010)^{25}\end{array}$ \\
\hline China & $1338.3 \mathrm{~m}$ & $5926.6 \mathrm{bn}$ & $114.3 \mathrm{bn}$ \\
\hline Iran & $73.9 \mathrm{~m}$ & $331.015 \mathrm{bn}(2009)$ & $7.04 \mathrm{bn}(2008)$ \\
\hline Russia & $141.8 \mathrm{~m}$ & $1479.8 \mathrm{bn}$ & $52.6 \mathrm{bn}$ \\
\hline Turkey & $72.8 \mathrm{~m}$ & $734.4 \mathrm{bn}$ & $15.6 \mathrm{bn}$ \\
\hline
\end{tabular}

The possibility of alliance with neighbours outside the region may outweigh the causal significance of the distribution of power within it.

A second contributing factor might be that, for much of the post-1991 period, the states of the region were variously weak. Many of the states' governments had little control over their territories and population. Two (Azerbaijan and Georgia) faced numerous internal ethnic and sub-state regional challenges that produced protracted civil conflict and intervention by neighbouring states. All were to varying degrees isolated from the global economy. At independence none of them had any experience in the conduct of foreign policy or instruments with which to conduct it.

In other words, the region was (and to an extent still is) disorganized, comprising weak and vulnerable states surrounded by more powerful neighbours. Realist theory would predict efforts by the weak to secure the support of larger powers, and a competition between the contiguous 
This is an Author's Original Manuscript of an article submitted for consideration in Nationalities Papers (৫ Taylor \& Francis); Nationalities Papers is available online at http://www.tandfonline.com/toc/cnap20/current\#.UkLdT1M9860

powers to influence the space between them, in other words a regional "great game". Here again, strict realist deduction does not help very much. Despite the vacuum between them, there has been little competitive alliance-building by the three contiguous powers.

The wider Eurasian region in turn is embedded in a global system, and is considered by many to be a key element of that larger system. ${ }^{26}$ Leaving aside Mackinderian extremes about the heartland ${ }^{27}$, more distant states might have strong interests in the evolving affairs of Central Eurasia. These include access to the region's natural resources, the opening of markets, and preventing the dominance of the region by any single great power. That suggests the possibility of balancing against sub-regional and regional power asymmetries through alignments with more distant partners.

Overall, this realist view of alignment is not terribly good at explaining and predicting the alignment of new and inexperienced states that have yet to situate themselves in an established balance of power. It is unclear how a parsimonious structural realist approach could cover the diversity of choice by states in similar geographical and power-political conditions briefly outlined above. That invites consideration of alternatives.

Stephen Walt pointed out that realist balance of power theory focused principally on the alignment decisions of great powers, and was not so useful in addressing the decisions of smaller states. ${ }^{28}$ He proposed an alternative: states tend balance not against power, but against threat. Weaker states may prefer to balance against threats, but will bandwagon with the threatening power when they lack balancing options. In Walt's view, the definition of threat assessment included four components: aggregate power, proximity, offensive capability, and perceived intention. ${ }^{29}$ The result is a theory that lacks the simplicity of structural realism, but which may provide a more accurate explanation of alignment. As I shall suggest below, this approach is useful in understanding the role of identity in Central Eurasia's alignment choices.

\section{Alternative Approaches}

Several other approaches to alignment should be mentioned. One is the possibility that states align with others in the expectation of profit. ${ }^{30}$ To the extent that alignments encourage greater trade, investment or development assistance, the utility of the receiving state or regime is enhanced.

By and large, the states we are talking about were net beneficiaries from the internal resource flows of the USSR. As the union collapsed, one might have expected them to seek close relations with Russia in order to retain this benefit. The Central Asian states resisted the dissolution of the USSR. When the union dissolved, they hoped that a close economic and security relationship could be retained. That assumed that Russia could, or would, continue to buy loyalty. The collapse of the Russian economy and Russia's sudden shift from status as a subsidizer of the republics of Central Eurasia to international aid recipient foreclosed this possibility. For much of the post-Soviet period, Russia lacked the capacity to sustain alignments by economic means. By 
This is an Author's Original Manuscript of an article submitted for consideration in Nationalities Papers (৫ Taylor \& Francis); Nationalities Papers is available online at http://www.tandfonline.com/toc/cnap20/current\#.UkLdT1M9860

the time its economy recovered in the 2000s, its economic influence had diminished while that of China in particular was growing rapidly.

Turning finally to identity, as suggested earlier, states may choose alignments on the basis of their conception of their own identities and those of their potential partners, what Wight referred to as "affinity" in the citation that begins this chapter. Equally, perceived differences of identity ("otherness") are a possible determinant of alliance behavior. Identity may reflect historical experience; shared history in theory may favour alignment. Cultural (ethnic, linguistic, and/or religious) ties may guide alignments.

Identity may also have an ideological component; shared ideological principles may influence alignment. It was widely believed during the Cold War that ideological affinity strengthened cooperative ties among communist states and states of socialist orientation in the Third World. Inasmuch as political structure reflects identity and values, shared political models may encourage alignment, a position implied in much democratic peace theory.

Several of these dimensions can be ignored because of lack of variation on the independent variables coupled with significant variation on the dependent one. All of the states of Central Eurasia share the Soviet experience; as such differences of alignment behaviour cannot easily be accounted for in terms of the historical legacy of the Soviet period. In Central Eurasia, ideology and political structure are also of limited significance for similar reasons. The states of the region are all semi-authoritarian and there are not any particularly large differences of economic approach, with the possible exception of Georgia. It is impossible to account for variation on the dependent variable (alignment) when the independent variable (historical experience or the nature of the units) shows little variation.

Cultural identity is more promising since there is large variation in the region in linguistic, ethnic and religious terms. The Caucasus and Central Asia are deemed to be a central "fault-line" in Samuel Huntington's "clash of civilizations." Huntington suggests that, in the absence of bipolarity, societies and states will align along civilizational lines and that civilizational identities will be significant drivers of conflict in the post-Cold War period. ${ }^{31}$

Finally, it may be that states do not follow any of these theoretical logics leading to alignment. Alignment is not the only strategic option available to states. They can hide, maneuver or hedge.

\section{Alignment in Central Eurasia}

As suggested earlier, alignment may involve the region's states with each other, with neighbouring states, or with more distant partners. It may be soft. NATO's Partnership for Peace Programme, for example, includes all the states of the region and involves cooperation in security sector reform, as well as training and joint exercises, but with no commitment to the security of the partner. ${ }^{32}$ It may be hard, in the sense of formal agreements committing parties to mutual support in the event of attack on one member by an outsider (for example, the CSTO or a number of bilateral defence treaties between Russia and Central Eurasian states ${ }^{33}$ ). 
This is an Author's Original Manuscript of an article submitted for consideration in Nationalities Papers (৫ Taylor \& Francis); Nationalities Papers is available online at http://www.tandfonline.com/toc/cnap20/current\#.UkLdT1M9860

\section{Alignment Behaviour within the Region}

Within Central Asia, and given the multifaceted interdependence (river basins and water, energy, transport) and shared problems (migration, transnational crime, economic diversification) of Central Asian states, as well as their shared geographical position in a region ringed by larger and sometimes threatening states, one might expect them to cooperate across a broad range of issues, including security. However, there is little evidence of any sustained or successful effort to build on these similarities and this interdependence to create alliances or other serious co-operative structures.

In conditions of scarcity, resource interdependence generates conflict rather more than cooperation, as in disputes over water from the region's shared river basins, and in occasional disputes between Uzbekistan and Kyrgyzstan over energy interdependence. Leadership within the region is constrained by latent rivalry between the region's two largest states and by the smaller states' lack of interest in the institutionalization of regional hierarchy. Bilateral relations are complicated by the artificiality of borders and a host of host-state, kin-state ethnic issues.

On the other hand, the states of the region have been able to cooperate on an ad hoc basis when they collectively face significant shared threats. When militants of the IMU repeatedly sought to penetrate Uzbekistan via Tajikistan and Kyrgyzstan in 1999-2001, the three states cooperated to prevent them. The other major shared threat is that of Western democracy and human rights promotion. In this context, regional leaders have cooperated in criticism of the OSCE's Office for Democratic Institutions and Human Rights for interference in internal affairs and the OSCE for insufficient attention to security and overemphasis on the "human dimension" in its dealings with the region.

The three states of the Caucasus face a similar geographic situation, sandwiched between Iran, Russia, and Turkey. They are highly dependent on each other's infrastructure. More precisely, both Armenia and Azerbaijan depend on Georgia for links to the Black Sea. However, there is again no substantial alignment among them, in the sense that alignment was defined earlier in this chapter. The capacity for trilateral alignment is highly constrained by the conflict between Armenia and Azerbaijan over Nagorno Karabakh.

Azerbaijan and Georgia have quite close bilateral relations, but it would be an exaggeration to call this an alignment. Closer Azerbaijani-Georgian security cooperation would be difficult for Georgia, since that would alienate Armenia, which has the most effective armed forces in the region, and has close security ties with Russia, Georgia's nemesis. In addition, there is a large Armenian minority in south-central Georgia, with close ties to their kin state. There is a consequent risk of internal majority-minority conflict in the event that Georgia tilted too far towards Azerbaijan. Similarly, a Georgian tilt towards Armenia would be difficult, given the importance of transit of energy and other goods through Georgia from and to Azerbaijan as a contribution to the Georgian economy and the presence of a large Azerbaijani minority Georgian districts contiguous to Azerbaijan. 
This is an Author's Original Manuscript of an article submitted for consideration in Nationalities Papers (৫ Taylor \& Francis); Nationalities Papers is available online at http://www.tandfonline.com/toc/cnap20/current\#.UkLdT1M9860

The mention of Russia leads to a discussion of alignment with states outside Central Eurasia. These relationships are both multilateral and bilateral.

Table 3. Regional Multilateral Alignment Relationships Comprising Central Eurasian States and Major Neighbours ${ }^{34}$

\begin{tabular}{|c|c|c|c|c|c|}
\hline & $\mathrm{CIS}$ & CST & CSTO & $\mathrm{SCO}$ & PfP \\
\hline Armenia & X (1991) & X (1992) & $X(2002)$ & & X (1994) \\
\hline Azerbaijan & X (1994) & X (1994-9) & & & X (1994) \\
\hline Georgia & $\begin{array}{l}X(1993- \\
2008)\end{array}$ & X (1994-9) & & & X (1994) \\
\hline Kazakhstan & X (1991) & X (1992) & $X(2002)$ & $X(2001)$ & X (1994) \\
\hline Kyrgyzstan & X (1991) & X (1992) & $X(2002)$ & $X(2001)$ & X (1994) \\
\hline Tajikistan & X (1991) & X (1992) & $X(2002)$ & $X(2001)$ & $X(2002)$ \\
\hline Turkmenistan & $X(1991)^{35}$ & & & $x$ & $X(1994)$ \\
\hline Uzbekistan & X (1991) & $X(1992-9)$ & $X(2006)$ & $X(2001)$ & X (1994) \\
\hline China & & & & $X(2001)$ & \\
\hline Iran & & & & & \\
\hline Russia & & X (1992) & $X(2002)$ & $X(2001)$ & X (1994) \\
\hline Turkey & & & & & \\
\hline
\end{tabular}

The major multilateral arrangements for security cooperation involving Central Eurasia are listed with membership in Table $3 .^{36}$

The CIS and the CST/CSTO

In its first decade, the Commonwealth of Independent States (CIS) had little impact on the decisions of its members. It was originally conceived as a mechanism to retain institutional and functional ties among members after the Soviet collapse. In the security area, covered by the CST, a joint force structure was envisaged. However, this soon broke down, in part because the Russian Federation, focusing on a westward-oriented policy, was not paying attention to its CIS partners in Central Eurasia. Moreover, given its economic dislocation, it was not in a position to 
This is an Author's Original Manuscript of an article submitted for consideration in Nationalities Papers (৫ Taylor \& Francis); Nationalities Papers is available online at http://www.tandfonline.com/toc/cnap20/current\#.UkLdT1M9860

generate incentives for the others to accept this hierarchical approach to cooperation. As Olcott, et.al., put it:

Senior Russian officials frequently complain about the lack of follow-through by the CIS partners, yet the Russian military budget is stretched paper thin, making Russia unable to finance basic projects in border protection, air defense, or collective security. ${ }^{37}$

When Russia started paying attention, its approach was mainly bilateral rather than within the context of the regional organization. In realist terms, if institutionalized cooperation is based on the preferences of a hegemonic power, the problem was that the logical hegemon was incapable of, and not obviously willing to, play the leading role.

The states of the region also lacked the capacity and, for the most part, the will to contribute meaningfully to a close and institutionalized regional area. By 1993, most states had opted for independent national militaries and were taking their own economic and political decisions outside cooperative structures, not least because they all faced substantial and immediate economic crises and the cooperative structure could not deliver credible solutions. The ruble zone meltdown in 1993 is an eloquent illustration.

In the area of crisis management, the CIS turned into a limited mechanism to give regional legitimacy to what were essentially Russian preferences. The CIS mandated a force to intervene in the civil war in Tajikistan in late 1992; the force was essentially Russian and its purpose was not peacekeeping but ensuring the survival of the incumbent government in the face of a challenge from hybrid Islamic/democratic opposition. A number of neighbouring states (e.g. Uzbekistan) supported this endeavour out of concern over the possible northward spread of radical Islamism from Tajikistan and Afghanistan.

The CIS belatedly authorized a peacekeeping force to separate the two sides in the Abkhaz conflict in Georgia, but the initiative (and the peacekeeping force) was Russian. No other CIS members participated. The CIS played no role in the Karabakh conflict, not least because Russia favoured the winner and supported Armenia in material terms. General Grachev's mediation of a cease fire in May 1994 was conducted outside the institutional frame. ${ }^{38}$

The Collective Security Treaty (CST), within the larger institutional context of the CIS, was signed in Tashkent in 1992. It was in essence a non-use of force and mutual assistance arrangement. In 2002, the CST was institutionalized in the Collective Security Treaty Organization (CSTO). The CSTO replicated the substance of the CST while broadening the remit to such issues as terrorism, illegal migration, crime and drugs trafficking. The members adopted a Charter defining a policymaking framework and a secretariat. It also provided a framework for joint forces (e.g. a rapid deployment force comprising elements of national military structures), for consultation of the stationing of forces of one member on the territory of others, and for joint exercises. ${ }^{39}$ The rapid deployment force, as it happened, had been established prior to the CSTO in 2001. A joint staff and military headquarters were set up in 2003 and a small counter-terrorism centre was established in Bishkek. 
This is an Author's Original Manuscript of an article submitted for consideration in Nationalities Papers (৫ Taylor \& Francis); Nationalities Papers is available online at http://www.tandfonline.com/toc/cnap20/current\#.UkLdT1M9860

One element of Table 3 that is noteworthy is that some members joined some institutions later than others, and some left. For example, both Georgia and Azerbaijan joined the CIS and the CST at the end of 1993. They both withdrew in 1999. Uzbekistan was an original signatory of the CST, but also withdrew in 1999.

Georgia joined both the CIS and the CST because of the painful outcome of the war in Abkhazia. It needed Russian assistance in managing a rebellion in Mingrelia. Also, Georgians hoped that if they were more compliant towards the Russians, the latter would assist in achieving an acceptable resolution of the Abkhaz and Osset conflicts. The price was joining these organizations, agreeing to the deployment of the Russian peacekeeping force mentioned above, and accepting long term basing arrangements for existing Russian forces in Georgia. ${ }^{40}$

The Georgian hope that compliance in CIS/CST structures would trigger Russian assistance in resolving its secessionist conflicts proved futile. As a result of the adjustment of US policy in the mid-1990s and the effectiveness of Georgian "friend-raising" in Washington, they had an alternative krysha. Having been disappointed by the results of it effort at accommodation with Russia, it began to explore the option of balancing with the United States. Georgia withdrew from the CST in 1999, and turned to the OSCE to secure the removal of Russian bases.

In the Azerbaijani case, in 1993 the country was in the last stages of a disastrous civil war and intervention by Armenia in Nagorno Karabakh. The Popular Front government of Abulfaz Elchibey had collapsed and Geidar Aliev had returned to power. The Armenians took advantage of the disruption in Baku to consolidate their position around Karabakh with further massive displacement of the Azerbaijani population in the affected districts. In short, the government needed breathing space to consolidate its position. In addition, it hoped that joining the CIS and CST might generate more constructive Russian engagement in the Karabakh conflict. Russia eventually delivered in its mediation of a durable ceasefire in May 1994.

By Azerbaijan's date of withdrawal from the CST, several things had changed. First, the government had gained full control of the politics of Azerbaijan and faced no significant internal threats. Second, revenue from the export of oil was beginning to flow, increasing the resource base of the government. The activation of Azerbaijani energy export also engaged Western governments and their interests more closely with Azerbaijan. Third, it had become clear that Russia had little interest to move beyond the ceasefire towards the achievement of a settlement that would be acceptable to the Azerbaijani leadership. Fourth, there had been no significant weakening of Russia's bilateral relationship with Armenia. The rational conclusion was to withdraw from the CIS/CST structure, which they did.

Just as the decisions of states to leave the CSTO are interesting in the explanation of alignment behaviours, so too are late decisions to join. Uzbekistan was an original signatory of the Tashkent Treaty, but withdrew from the collective security in 1999 (for a time exploring the GU(U)AM structure instead). This was followed in turn by flirtation with the United States in the context of US operations in Afghanistan. That ended when the United States, among others, 
This is an Author's Original Manuscript of an article submitted for consideration in Nationalities Papers (৫ Taylor \& Francis); Nationalities Papers is available online at http://www.tandfonline.com/toc/cnap20/current\#.UkLdT1M9860

criticized the $\mathbf{2 0 0 5}$ massacre of civilians in the Uzbek town of Andijan by government forces. Russia, on the other hand, supported the crackdown. The Uzbek government evicted US forces from military facilities in the country. In 2006, Uzbekistan joined the CSTO.

The Russian invasion of Georgia in August 2008 gives a good measure of the regional security significance of CIS and CSTO structures. Russian diplomats tried mightily to secure endorsement of the action from CIS partners. Not one endorsed their action or the subsequent dismemberment of the country. None has recognized the Abkhaz and South Ossetian de facto authorities.

The second major multilateral initiative affecting part of Central Eurasia is the SCO. The organization emerged out of informal cooperation on border cooperation and other matters in the "Shanghai Five" (China, Kazakhstan, Kyrgyzstan, Russia, and Tajikistan). The successor organization was designed in 2001, at which time Uzbekistan was added. In 2002, member states signed its charter.

The charter greatly extended the purview of cooperation in economic and social affairs, while extending the security remit to counter-terrorism. The latter took tangible form with the opening of a counter-terrorism centre in Tashkent in the context of a regional counterterrorism structure (RATS). The structure also addresses cross-border narco-trafficking issues. The organization is "soft" in alliance terms (no mutual defence guarantees), which is not surprising given the pre-existence of the CSTO, and also the potential conflicts of interest between its major members, Russia and China.

\section{Bilateral Alignment Issues across Central Eurasia's Borders}

These alignments and loose structures of security cooperation do not tell us much about the role of identity in alliance behaviour. Indeed, CIS/CSTO security cooperation (the most substantial in formal terms) is by and large a multilateral framing of what are essentially bilateral relations with the Russian Federation. This draws attention to bilateral relations between the region's states and outside actors. They can be loosely grouped into the four types of behavior, discussed in the earlier section on theory: hiding, bandwagoning, fence-sitting, and balancing. ${ }^{41}$ These categories are, however, analytical conveniences; most states in the region combine elements of more than one at the same time and often shift between them over time.

Of the states of the region, the most consistent "hider" is Turkmenistan, which, as noted earlier, declared neutrality early and has stayed with that policy.

The most consistent bandwagoning state is Armenia, which forged a close security relationship with Russia upon independence and has retained it, the latest phase being the renewal of the bilateral defence arrangement in 2010. Kazakhstan is in the same category. After initially supporting a strong CIS, Kazakhstan has steadily sought to maintain a closed multifaceted (security, economic, and political) relationship with Russia, and has participated willingly in a long series of subregional economic cooperation agreements, the latest of which is Putin's 
This is an Author's Original Manuscript of an article submitted for consideration in Nationalities Papers (৫ Taylor \& Francis); Nationalities Papers is available online at http://www.tandfonline.com/toc/cnap20/current\#.UkLdT1M9860

Eurasian Union. ${ }^{42}$ Tajikistan is close behind, its adherence to such structures being limited more by other members' reluctance to take on its burdens than by any desire on its part for policy autonomy.

Kyrgyzstan has tried to sit on the fence by maintaining close relations with Russia and participating in Russia-centred economic and security arrangements while developing close relations with the West, and the United States in particular, without alienating Russia. A good example of this ambivalence is the existence of both Russian (Kant) and American (Manas) military bases on Kyrgyzstan's territory.

Uzbekistan is the most obvious fence-sitter. Although it joined the CIS and signed the CST in 1991 and 1992, it did little to implement its formal commitments. Having regional great power aspirations of its own, it sought to limit Russian influence in the Central Asian region. As noted earlier, it withdrew from the Tashkent Treaty in 1999. After the US invasion of Afghanistan in 2001, the Uzbeks offered the use of military bases for the American effort. Uzbekistan also sat out the formative years of the SCO, joining when it transformed itself into a formal organization in 2001-2.

After American and European criticism of its handling of the Andijan crisis, the Uzbek government pulled back from its flirtation with the West, evicted the US military from the country and joined the Sino-Russian call for the withdrawal of Western military forces from Central Asia. The ostensible Russian tilt in Uzbek policy was capped off by Uzbekistan's decision to join the CSTO in 2006. However, this move is hardly complete. Uzbekistan uses the growing role and presence of China in the region to maintain room for maneuver vis-à-vis Russia. To put it another way, it sits on a different fence.

Azerbaijan provides another example of fence-sitting. Russian support of Armenia during the Karabakh war gives the country good grounds for resisting Russian influence in the southern Caucasus. Azerbaijan's economic interests have the same effect. The Azerbaijani government has steadily defied Russian efforts to control energy export from the Caspian region by promoting east-west energy infrastructure across the southern Caucasus and limiting its export of gas and oil through Russian pipelines. On the other hand, it has taken care to limit its politicomilitary association with Western institutions. This reflects the inconsistency of Western norms of governance with Azerbaijani authoritarian practices. But Azerbaijan's ambivalence to these institutions also makes sense as a means of limiting risk in its relations with Russia. After the Georgia war in 2008, it acted to improve its relations with Russia on a number of fronts for the same reason.

The most striking example of balancing vis-à-vis Russia is that of Mikheil Saakashvili's Georgia, since 2004. Since 2003, Georgia has consistently underlined its European identity, and has emphasized its aspiration to integrate into European institutions, notably NATO. It participated significantly in US-led operations in Iraq and as of 2012 was the largest non-NATO contributor to the NATO-led International Security and Assistance Force (ISAF) in Afghanistan. 
This is an Author's Original Manuscript of an article submitted for consideration in Nationalities Papers (৫ Taylor \& Francis); Nationalities Papers is available online at http://www.tandfonline.com/toc/cnap20/current\#.UkLdT1M9860

The variety of alliance behaviours and the changeability of relationships suggests there is no parsimonious explanation for the region as a whole, although there may be for specific countries.

\section{Analysis}

As discussed earlier, theory provides several possible ways in which to understand alliance choice. Structural realist analysis focuses on the role of the distribution of power in a self-help environment populated by states whose primary interest is survival. It suggests that these actors will more often than not align against superior power, generating a pattern of balance in which no single state dominates the system. Although this approach may have some use in accounting for patterned relationships among major powers, its predictions seem less plausible with respect to small and weak states, where aligning with power rather than against it is more common.

The most influential revision of realism to take account of this problem is that of Stephen Walt, who suggested that states react more to threats than to power. The perception of threat rests on aggregate power, proximity, offensive military capability, and perceived intention (hostile or not).

The last element opens the door to consideration of identity in the context of broader theoretical discussion of alliance behaviour. Identity-based analysis would suggest alliance based on affinity. In addition, identity issues can generate the political/security conditions (security dilemmas) that drive alignment, thereby having an indirect effect on alliance choice. Finally, identity can serve as a useful instrument in securing assistance required for other reasons.

One can depict these possibilities in an arrow diagram as follows:

Figure 1. Identity and Alliance ${ }^{43}$

1. Threat $\quad \rightarrow \quad$ Alliance

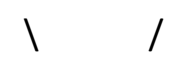

[Identity]

2. Identity $\rightarrow \quad$ Threat $\quad \rightarrow \quad$ Alliance

$\begin{array}{llllll}\text { 3. Identity } & -> & \ldots & & & \\ & & & & \end{array}$

The figure contains three possible causal relationships. One is threat perception leading to alliance, without reference to identity. The second proposes that identity conflict may be a condition antecedent to threat perception. The square-bracketed reference to identity between 
This is an Author's Original Manuscript of an article submitted for consideration in Nationalities Papers (৫ Taylor \& Francis); Nationalities Papers is available online at http://www.tandfonline.com/toc/cnap20/current\#.UkLdT1M9860

lines one and two suggests that identity (affinity or the deliberate construction of purported affinity) may play an instrumental role as an intervening variable influencing the receptivity of potential partners to regional alignment strategies. The third line proposes an unmediated causal relationship between identity and alliance choice.

To my mind, there are no clear examples of variants 1 and 3. The reason for the absence of cases for the first variant is fairly straightforward. Short of massive and imminent danger, the definition of threat presupposes perception of intent. That perception is closely related to identity. $^{44}$

Variant 3 is problematic in the first place because it is not clear why states would align purely on identity grounds in the absence of some threat against which to align. Moreover, alignment choice based on affinity presumes strong and stable identities. This recalls the discussion of contestation in the introduction to this chapter. The identities of most Central Eurasian states are still in formation. They remain substantially contested because of sub-state regionalism and localism, differences over the role of religion in government and law, secularism versus religion in governance, and ethnic divides. The major threats to the region's states and the region's major conflicts have all been internal. ${ }^{45}$ Transborder links between minority ethnic groups and nearby kin states, and transnationalism in religious movements also produce contestation. ${ }^{46}$

There are numerous regional examples of the middle chain: identity issues contributing to the perceptions of threats to which alliance behaviour responds. There are also examples of identity being used instrumentally in order to win over a potential partner. These propositions may be illustrated through analysis of two cases: the Nagorno-Karabakh conflict and the conflict between Russia and Georgia.

\section{Identity, Threat and Alignment in the Karabakh Case}

The Karabakh conflict arose in some measure out of different Armenian and Azerbaijani conceptions of the relationship between identity and territoriality. Each side perceived the Karabakh region as central to their self-conception. The conflict itself had deep identity characteristics, not least in widespread displacement of each side's co-ethnics (Armenians from Baku, Azerbaijanis from Yerevan, and Azerbaijanis from Karabakh and adjoining districts) as well as targeted attacks on civilians of the other group (e.g. Armenians in Sumgait and Baku and Azerbaijanis in Khojalu) that strengthened the identity element of the dispute further. These events have had a substantial effect on national and state identity on both sides.

In these circumstances, both sides sought allies. Their need for allies was driven by the conflict within which they were involved. However their choice of allies reflected understandings of shared or conflicting identity. For example, the long history of identity conflict between Armenia and Turkey, not least the mass killings of Armenians in the Ottoman Empire during World War I, informed Armenia's perception of Turkey as a hostile and threatening neighbour. That perception encouraged balancing against threat through alliance with the former Soviet regional great power, Russia. That choice was conditioned by a longstanding and widespread perception 
This is an Author's Original Manuscript of an article submitted for consideration in Nationalities Papers (৫ Taylor \& Francis); Nationalities Papers is available online at http://www.tandfonline.com/toc/cnap20/current\#.UkLdT1M9860

of Russia as Armenia's protector against Turks ${ }^{47}$, as well as a shared sense that Islam was a threat to both.

Threat perception rooted partially in identity also may explain in part, and in a similar way, Armenia's desire for close relations with Iran since independence. This bilateral is a good example of the complexity of the question of identity and alliance. From Armenia's point of view, there is no direct identity or ideational basis for its cultivation of Iran. ${ }^{48}$ However, faced with hostility from Azerbaijan and Turkey, it sought security through relations with the other regional great powers, including Iran. That sounds like a classically realist situation.

But it gets more interesting when you turn the tables. Why would Iran want a relationship with Armenia? There is again a straightforward realist answer: Iran is uncomfortable with the expansion of Turkish influence in the region and the tie between Turkey and Azerbaijan. It therefore makes sense to balance against Turkey with Armenia and Armenia's major partner, Russia.

However, identity issues may have accelerated this Iranian balancing. What was the nature of the threat from Azerbaijan against which Iran balanced? There is a very large concentration of Azerbaijanis in northwestern Iran (a.k.a. Southern Azerbaijan). The issue of the reunification of Azerbaijan has long been a staple of Azerbaijani nationalism. Iranian identity narratives have tended to emphasize the existence of one nation, and a discomfort with the politicization of sub-state ethnic identity. Azerbaijani irredentism challenges Iranian identity myths and also potentially Iran's territorial identity.

Azerbaijani concerns about their coethnics across the border reemerged strongly after the collapse of the USSR, and were actively discussed under (and by members of) the Popular Front government in Baku in 1992-3. ${ }^{49}$ As Swietochowski notes, from an Iranian perspective, the concern was Tabriz. Behind Azerbaijan stood Turkey. Behind Turkey stood the United States. ${ }^{50}$ Another relevant identity issue was Turkish and Azerbaijani secularism in politics, which directly contradicted Iran's theocratic conception of the state. It was during this period that the basis of Iran's post-USSR relationship with Armenia was laid. In short, Iran's alignment choices were closely bound up with its identity concerns, and cannot be understood without reference to those concerns.

Identity affinity based on language and culture also matters in Azerbaijani-Turkish relations. It is further strengthened by the existence of a large and long-established Azerbaijani diaspora in Turkey. Turkey at various times has conceived itself as the centre of a large pan-turkic community stretching across the Caucasus and into Central Asia, of which Azerbaijan is a major part. Iran's merger of religion and statehood runs counter to Azerbaijani and Turkish conceptions of secularism in politics. The question of relations with Armenians and Armenia is deeply rooted in the histories of both countries.

Identity, Threat and Alignment in Georgia 
This is an Author's Original Manuscript of an article submitted for consideration in Nationalities Papers (৫ Taylor \& Francis); Nationalities Papers is available online at http://www.tandfonline.com/toc/cnap20/current\#.UkLdT1M9860

A second example would be the nexus of relations around Georgia's conflicts over the last twenty years. Georgia's alliance behaviour over this period has been largely determined by a quest for security in the face of domestic conflict and the intrusiveness of Russia. If one begins with the return of Eduard Shevardnadze in early 1992, one encounters an early effort to secure support from Western European states and the United States in Shevardnadze's efforts rebuild the state and to protect the country from neighouring Russia. When this failed, Georgia sought to secure Russia's cooperation through joining the CIS and the CSTO. When this did not produce a resolution of the country's conflicts or a reduction in Russian interference with Georgia's efforts to stabilize the state and restore its control over Abkhazia and South Ossetia, Shevardnadze tilted back towards the West. This tendency accelerated under Saakashvili, further alienating Russia and ultimately producing a short war in 2008, one purpose of which was to make the point that the Caucasus was Russia's backyard. All of this has classic realist ring to it.

Once again, however, when you enquire as to the origins of Georgia's security conundrum, you immediately run into issues that fall squarely into the realm of ideas and identity. When Georgian nationalism and national identity emerged in the $19^{\text {th }}$ Century, it was russophile. As Aleksandre Chavchavadze put it soon after Russia's conquest of eastern Georgia, Russia "opened the way and gave the Iverians hope that enlightenment would spread among them." ${ }^{51}$ For many Georgian intellectuals at this time, the Russian Empire was a path towards overcoming the consequences of centuries of division, occupation, and backwardness. In addition, the Georgian intelligentsia strongly held that Russian protection was necessary to ensure the survival and prospering of a modernizing Georgia in the face of threats of invasion from the south.

Although the Georgian nationalist movement moved towards socialism and social democracy and became increasingly critical of the Russian monarchy, it did not equate this with a desire for independence from Russia, seeking instead a place for Georgia within a democratic and socialist Russian state. When the social democrats took power in Georgia in 1918, the declaration of independence was a reflection of the collapse of central Russian governance and the need for sovereign powers to cope with an economic, social, and military crisis. ${ }^{52}$

By the time of the collapse of the Soviet Union, there had been a near-complete reversal in the place of Russia in Georgia's national identity. At one level, this reversal reflected the Soviet experience and notably the Stalin period. It was clear that "Russia" held the potential to be a serious threat to Georgians' self-identification and national aspirations. The ultimate expression of this threat was the attack by Soviet troops on Georgian demonstrators in April 1989 when over twenty people were killed by trench shuffles and poison gas. The imperative of protection was less compelling for Georgia by this stage since, unlike for the Armenians, Turkey (and for that matter Azerbaijan) were not seen to be imminent threats. ${ }^{53}$

The virulence of russophobia in the early days of independence under Gamsakhurdia may have contributed to Russia's informal support of secessionist movements in Georgia. That support also reflected a lingering imperial identity. However, the fundamental reason for the initial 
This is an Author's Original Manuscript of an article submitted for consideration in Nationalities Papers (৫ Taylor \& Francis); Nationalities Papers is available online at http://www.tandfonline.com/toc/cnap20/current\#.UkLdT1M9860

conflict (South Ossetia) was the post-Soviet Georgian government's conceptualization of Georgian identity - Georgia was "for the Georgians." Autonomous structures within Georgia were illegitimate Soviet impositions designed to weaken Georgia. Given Georgian nationalist perception of Ossetian disloyalty during the first Georgian republic (1918-21), and longstanding Ossetian cooperation with Russians in the North Caucasus, the Ossetians were deemed suspect. So, when the Ossetians began to question their status, Georgia annulled their status. The Ossetians rebelled.

A similar dynamic was evident in Abkhazia. Unlike the Ossetians, or for that matter the Georgians, the original moment of formation of Abkhaz identity was one of extreme hostility to Russia. The Russian government committed what we might now call genocide against the Circassians in the North Caucasus. They subsequently expelled a very large portion of the Abkhaz community in north-western Georgia in what would now be called ethnic cleansing. The Abkhaz, demographically vulnerable as a result of Russian depredations, clung to their identity through the late imperial period, and the period of the first Georgian republic.

Soviet power created an opportunity for reconsolidation. Abkhazia was established as a union republic in association with Georgia within the Transcaucasian Federative Soviet Socialist Republic. In the 1930s, the Soviet government downgraded Abkhazia's to status to that of an autonomous republic within Georgia. Large scale migration of Georgians (and Russians and Armenians) to Abkhazia followed, such that, by 1989 , the ethnic Abkhaz made up only $18 \%$ of the population of Abkhazia. The 1970s and 1980s were a period of increasing Georgian challenge to Abkhaz identity, producing a nationalist reaction. The situation gradually descended into the war in Abkhazia in 1992-3.

In other words, competing definitions and redefinitions of identity generated threats for both the Georgians and their minorities. They all sought to manage these threats through alliance formation. Identity did not generate the alliances. Identity generated the power-political challenges to which alliance formation was a response.

\section{Other Examples}

A similar pattern of responding to identity based security challenges is evident in Central Asia. For example, the civil war in Tajikistan grew out of rivalries for power and control over state resources between elite factions within the communist party. These elites were often centred on particular regions of the country (Khojend, Kulyab, among others). ${ }^{54}$ They had an interest in fostering regional identity narratives to consolidate their base. In this sense, the regionalization of Tajik identity may be a product of conflict as much as it is a cause.

In addition the arrival of political Islam unsettled the largely secular ruling elites, as well as the Uzbek government, and, for that matter, the Russian government. These factors generated security issues that both sides sought to resolve through alliances, the government with Russia and the opposition with the Afghan mujahedeen. 
This is an Author's Original Manuscript of an article submitted for consideration in Nationalities Papers (৫ Taylor \& Francis); Nationalities Papers is available online at http://www.tandfonline.com/toc/cnap20/current\#.UkLdT1M9860

In Kazakhstan, the care that the Kazakh government took after independence to ensure a positive relationship (that turned into a soft alignment) with Russia reflected not only the fact that Russia was more powerful and Kazakhstan was vulnerable, but concern about the loyalties of the large Russian and russophone population in northern Kazakhstan and about nationalist irredentism in the Russian Federation itself. Once again, the state sought to manage problems generated partly out of identity through alliance behaviour, in this instance to mitigate potential internal challenges as well as to protect against evolving identity narratives in Russia. One reason for Kyrgyzstan's tilt towards Russia was the presence of a large Uzbek minority in southern Uzbekistan and the general contempt that the Uzbek government held for the Kyrgyz, coupled with the power asymmetry between the two states.

In all these cases, we see that identity issues played a significant role in generating the risks and threats that Central Eurasian states sought to address through alliances with others. In other words, it was not so much identity-based affinity that generated alliance behaviour, but identitybased threats.

\section{The Instrumental Role of Identity in Alignment}

As suggested in Figure 1, the other role identity played was as an instrument in pursuing security relationships and wider assistance to mitigate threats faced by the state. That is, some Central Eurasian states used perceptions of affinity to secure assistance in dealing with threats to their security. The relationship between Azerbaijan and Turkey is illustrative. Leaving aside whether the relationship was based on "genuine" mutual affinity (ethnicity, secularism), the appeal for assistance based on ethnic markers has been effective, not least in the 1993 Turkish decision to embargo Armenia in the face of the Armenian offensive in Kelbajar.

Affinity can also be used - where it is perceived to exist - to alter the policies of the partner state. The effect was clear in the stalling of the Turkish effort to normalize relations with Armenia in 2010. The Zurich Protocol's de-linking of normalization from the Karabakh question ran into serious trouble in Turkish public opinion and in the Turkish parliament, because it was perceived by many as a betrayal of a "kindred" people.

A second example is that of Armenian use of the diaspora in the United States not only to secure assistance from America (to the extent that Armenia joined Israel as the top per capita recipient of US official development assistance), but also to affect US policy towards Azerbaijan (viz. Section 907 of the Freedom Support Act).

The third is that of Georgian relations with the United States. After the Rose Revolution, the Saakashvili government played strongly to the democracy promotion element of the George W. Bush Administration's foreign policy, embracing liberal economic reforms, and embracing (rhetorically at least) the concept of democracy. The Bush Administration reciprocated, hailing Georgia as a "beacon of liberty" in the region, and radically increasing flows of ODA and other assistance to Georgia. 
This is an Author's Original Manuscript of an article submitted for consideration in Nationalities Papers (৫ Taylor \& Francis); Nationalities Papers is available online at http://www.tandfonline.com/toc/cnap20/current\#.UkLdT1M9860

In fact, there is no evidence of substantial democratization in Georgia since the Rose Revolution. ${ }^{55}$ The discrepancy between the rhetoric and the reality in Georgia suggests that, at least in respect of democratization, the significance of ideological affinity was instrumental.

\section{Conclusion}

In this paper, we have examined the relationship between identity and alliance in Central Eurasia. We began by discussing various possible theoretical approaches to the explanation of alliances, including identity, the distribution of power, domestic political and ideological similarities, and "alliance for profit." That was followed by an empirical account of alignment behavior in the region and by analysis of reasons for that behaviour.

Several general conclusions may be suggested. First, with the exception of Armenia-Russian relationship and, to a lesser extent, the Azerbaijani-Turkish relationship, alignments have tended to be weak, ambivalent, and unstable.

To recall the citations that began this chapter, there is little support for Wight's conception of affinity-based "natural" alliance. There is even less support in this region for grand identitybased constructs such as the "clash of civilizations." States generally respond to the strategic context, rather than to identity-based affinity, in their alliance choices. In doing so, they often make choices that have nothing to do with shared or similar identity.

However, Palmerston's notion of "permanent interest" is also flawed. Although alliance choices are guided by conceptions of interest and threat, those interests and threats are not permanent. They are constructed in a dynamic strategic context defined in part by the development and intersection of identities.

Identity appears to play two significant roles in alliance behaviour in Central Eurasia. The first is that identity issues shape the strategic context (the landscape of threat) in which states define their security policies, including their alliance choices. Second, in a limited number of cases, identity-based affinity can be an instrument to influence the choices of potential allies. In these respects, identity is an unavoidable element of the explanation of alignment in Central Eurasia.

\section{Acronyms}

CIS

CSTO

EU

GTEP

GU(U)AM

NATO
Commonwealth of Independent States

Collective Security Treaty Organization

European Union

Georgia Train and Equip Program (US)

Georgia/Ukraine/(Uzbekistan)/Azerbaijan/Moldova

North Atlantic Treaty Organization 
This is an Author's Original Manuscript of an article submitted for consideration in Nationalities Papers (৫ Taylor \& Francis);

Nationalities Papers is available online at http://www.tandfonline.com/toc/cnap20/current\#.UkLdT1M9860

PfP Partnership for Peace (NATO)

SCO Shanghai Cooperation Organization

SIPRI Stockholm International Peace Research Institute

US $\quad$ United States

USSR Union of Soviet Socialist Republics

${ }^{1}$ S. Neil MacFarlane is Lester B. Pearson Professor of International Relations at the University of Oxford. In 2009-2013, he is a visiting professor at the Centre for Social Sciences, Tbilisi State University, Georgia. The author is grateful to participants in a seminar at the Tbilisi State University's Center for Social Sciences in 2011 where this paper was discussed. He is also grateful for for the useful comments of an anonymous reviewer.

${ }^{2}$ Martin Wight, Power Politics (London: Continuum, 1995), p.123.

3 "Speech in the House of Commons," 1 March, 1848.

${ }^{4}$ Stephen M. Walt, The Origins of Alliances (Ithaca, NY: Cornell University Press, 1987), p.12. Walt uses the terms alignment and alliance interchangeably.

${ }^{5}$ Rawi Abdelal, Yoshiko M. Herrera, Alastair lain Johnston, and Rose McDermott, "Identity as a Variable" (Cambridge, MA: Harvard Identity Project, 2005), p.2.

${ }^{6}$ Group identity may also be socio-economic in content, referring, for example, to profession or class. Gender, or sexual orientation, may also be an important element of identity. Since this paper concerns state behaviour, these aspects of identity are not discussed.

${ }^{7}$ Ibid., pp.1-2.

${ }^{8}$ Georgia provides a good example. Stephen Jones shows that in the last half of the $19^{\text {th }}$ Century, Georgians of all classes and political identifications believed that their being in the Russian state was a necessary condition for the preservation and flourishing of their identity. In the $21^{\text {st }}$ Century, Russia is seen by many Georgians, and certainly by the Saakashvili government, as an existential threat to Georgian statehood and identity. Stephen F. Jones, Socialism in Georgian Colors: The European Road to Social Democracy, 1883-1917 (Cambridge: Harvard University Press, 2005); and S. Neil MacFarlane and George Khutsishvili, "Ethnic Conflict in Georgia," in Symeon A. Giannakos, ed., Ethnic Conflict: Religion, Identity, and Politics (Athens, OH: Ohio University Press, 2002).

${ }^{9}$ As cited in Jones, op.cit., pp.165-6.

${ }^{10}$ Benedict Anderson argued that many national identities are the deliberate product of the efforts of intellectuals, officials, and political figures in Imagined Communities (New York: Verso, 1983).

${ }^{11}$ For a concise illustration of this methodological problem, see David Collier, Jason Seawright, and Gerardo Munck, “The Quest for Standards: King, Keohane, and Verba's Designing Social Inquiry," in Henry 
E. Brady and David Collier, eds., Rethinking Social Inquiry: Diverse Tools, Shared Standards (Lanham, MD: Rowman and Littlefield, 2004), pp.33-35.

12 The best known of these efforts is the GU(U)AM grouping, formed in the mid-1990s. GUAM (Georgia, Ukraine, Azerbaijan, Moldova) was founded as a consultative forum in 1997. Uzbekistan joined in 1999, but withdrew (formally) in 2005. The organization was formalized in 2001 when a Charter was adopted. In 2006, a GUAM peacekeeping force was proposed. Also in 2006, the organization was renamed the GUAM Organisation for Democracy and Economic Development. The official website is available at: http://www.guam-organization.org/en/node. Accessed 15 March, 2012.

${ }^{13}$ The unevenness reflected Russia's internal challenges and evolving policy capacity, but also a degree of uncertainty over the extent to which it can and should pursue a sub-regional, as opposed to a European, or a global focus in its foreign policy.

${ }^{14}$ Turkey's variable engagement also reflected an aspiration/capability gap, particularly in the early years, and an uncertainty over the eastward (Turkic and Muslim) or westward (European and EU) direction of its foreign policy. The latter in turn depends on the evolution of Turkey's relations with the European Union and the vicissitudes of Turkey's accession "process". Finally, it reflected wariness of the former and possibly re-emerging dominant power, Russia.

${ }^{15}$ The Shanghai Cooperation Organization originated in 1996 out of discussions on economic and border security cooperation among the "Shanghai Five" - China, Kazakhstan, Kyrgyzstan, Russia, and Tajikistan. Uzbekistan joined in 2001. The members adopted a charter in 2002, transforming it into a regional organization. Security cooperation, including border security and counter-terrorism remain a central element of the organization's activities.

${ }^{16}$ See, for example, Michael Barnett, “Identity and Alliances in the Middle East," pp.400-450, notably 410. Barnett suggests a direct link between identity and alliance behaviour in the Middle East.

${ }^{17}$ Wight, Power Politics, p.125.

${ }^{18}$ Waltz, Theory of International Politics (New York: McGraw Hill, 1979), pp.125, 166-7.

${ }^{19}$ World Bank Data Indicators, "Total Population." Available at: http://data.worldbank.org/indicator/SP.POP.TOTL/countries. Accessed 15 March, 2012.

${ }^{20}$ World Bank Data Indicators, “Current GDP.” Available at: http://data.worldbank.org/indicator/NY.GDP.MKTP.CD/countries. Accessed 15 March, 2012.

${ }^{21}$ SIPRI, “The SIPRI Military Expenditure Data Base.” Available at: http://milexdata.sipri.org/result.php4. Accessed 15 March, 2012.

${ }^{22}$ See Waltz's observation that secondary states will join the weaker of two coalitions, in Waltz, Systems of States, pp.126-7.

${ }^{23}$ World Bank, (note 19).

${ }^{24}$ World Bank, (note 20). 
${ }^{25}$ SIPRI, (note 21).

${ }^{26}$ E.g. Robert Legvold, "Introduction," in Robert Legvold, ed., Thinking Strategically: The Major Powers, Kazakhstan, and the Central Asian States (Cambridge, MA: MIT Press, 2003).

27 "Who rules Eastern Europe commands the Heartland, who rules the Heartland commands the World Island: who rules the World Island commands the World." Halford Mackinder, "The Geographical Pivot of History," Geographic Journal 23:4 (1904), pp.421-44.

${ }^{28}$ Walt, Origins of Alliances, (note 4), p.x.

${ }^{29}$ Ibid., p. vi and passim.

${ }^{30}$ Randall Schweller, "Bandwagoning for Profit: Bringing the Revisionist State Back In," International Security 19:1 (summer 1994), pp.73-107.

${ }^{31}$ Samuel Huntington, The Clash of Civilizations and the Remaking of World Order (New York: Touchstone, 1997).

${ }^{32}$ For a summary of the PfP rationale and activities, see: NATO, The Partnership for Peace Programme. Available at: http://www.nato.int/cps/en/natolive/topics 50349.htm. Accessed 15 March, 2011.

${ }^{33}$ See, for example, the bilateral defence arrangement between Russia and Armenia. For detail, see Breffni O’Rourke, “Russia, Armenia Sign Extended Defense Pact," Radio Free Europe/Radio Liberty (20 August, 2010). Available at: http://www.rferl.org/content/Russian President Medvedev To Visit Armenia/2131915.html. Accessed 15 March, 2012.

${ }^{34}$ The CSCE/OSCE is not included because it is not an alliance or alignment. All former Soviet republics are members. There is no variation on the dependent variable.

${ }^{35}$ Turkmenistan joined but has not ratified the Charter, which means that it is not an official member.

${ }^{36}$ I do not list the GU(U)AM arrangement because it has had no signifance on the region's security.

${ }^{37}$ Martha Brill Olcott, Anders Aslund, and Sherman W. Garnett, Getting It Wrong: Regional Cooperation and the Commonwealth of Independent States (Washington, DC: Carnegie Endowment, 1999), p.78.

${ }^{38}$ The failure of the CIS as a regional international institution in the 1990s is captured well in ibid., passim. For an account of CIS peacekeeping in Georgia in the same period, see S. Neil MacFarlane, "On the Front Lines in the Near Abroad: The CIS and the OSCE in Georgia's Civil War," in Thomas Weiss, ed., Beyond UN Subcontracting: Task-Sharing with Regional Security Arrangements and Service-Providing NGOs (London: Macmillan, 1998).

${ }^{39}$ An English text of the treaty may be found at: http://www.dkb.gov.ru/start/index aengl.htm. Accessed 15 March, 2011. 
${ }^{40}$ The latter, however, was subject to ratification by Georgia's parliament, which never occurred. The basing agreement was probably tactical; the ratification process could be (and was) drawn out and there was little prospect of success.

${ }^{41}$ See Paul Schroeder, "Historical Reality versus Neo-Realist Theory," International Security 19:1 (1994). Hiding, in his view, is a much practiced alternative to balancing or bandwagoning behaviour. On p.117, he defines hiding as: "simply ignoring the threat or declaring neutrality in a general crisis; possibly approaching other states on one or both sides of a quarrel to get them to guarantee one's safety; trying to withdraw into isolation ...."

${ }^{42}$ For a brief analysis of Putin's initiative, see Elkhan Nuriyev, "Putin's Plan for Russia's Neighbours - A Eurasian Union," Open Democracy (19 March, 2012). Available at: http://www.opendemocracy.net/odrussia/elkhan-nuriyev/putin\%E2\%80\%99s-plan-for-russia\%E2\%80\%99s-neighbours-eurasian-union.

Accessed 20 March, 2012.

${ }^{43}$ The causal directions in this figure are uni-directional. However, conflict and alignment can have a reverse effect on the conception of identity itself.

44 There are exceptions in extreme situations. When Germany attacked Russia in 1941, Winston Churchill declared in Parliament that "If Hitler invaded hell, I would at least make a favourable reference to the devil in the House of Commons." As Waltz said, "If pressures are strong enough, a state will deal with almost anyone." Waltz (note 18), p.166. But in Central Eurasia, the environment continues few substantial external threats to state survival.

${ }^{45}$ Georgia's war with Russia in 2008 was a partial exception. That war was rooted in the internal contestation of identity in Georgia, but these conflicts were exploited by Russia throughout Georgia's independence. The war itself was in key respects a classic interstate conflict, with one state taking advantage of another's vulnerability to attack it and take territory. Given the existence of a proximate, major state-based threat, it is no surprise that Georgia is the region's most consistent balancer.

${ }^{46}$ Armenia is the clearest exception here. It is essentially monoethnic, has no significant sub-state regional tensions, has a religious denomination embraced by the vast majority of the population, and displays no significant societal disagreement over the relationship between religion and politics. The historical rootedness of Armenian identity and the conception of Russia embedded in that identity are one reason that its alignment with Russia has endured.

${ }^{47}$ For discussion of the Russian image as protector of the Armenians, see Ronald Grigor Suny, Looking toward Ararat: Armenia in Modern History (Bloomiington, IN: Indiana University Press, 1993), passim. Suny notes, however, that the degree of this sentiment has varied across Armenia's modern history. In periods of stable Russian control, tensions have often arisen between Armenian nationalist elite and Russia, largely as a result of Russian policy.

${ }^{48}$ However, it is worth noting that Armenians in Iran or in Iranian-controlled territory have been better treated than they were in the later stages of the Ottoman Empire in Anatolia. 
49 Tadeusz Swietochowski notes the reference to this issue in the 1989 PFA programme: "While recognizing the indisputable nature of the borders between the USSR and Iran, the Popular Front supports the restoration of the ethnic unity of Azerbaijanis living on both sides of the border.", in Russia and Azerbaijan: A Borderland in Transition (New York: Columbia University Press, 1995), p.200. This was confirmed by author interviews in Baku in 1992, 1993 and 1995-6.

50 lbid., p.223.

${ }^{51}$ As cited in Stephen Jones (note 8), p.7.

52 This history is superbly discussed in ibid., passim.

53 The Ottoman Empire had disappeared along with its extra-Anatolian territorial pretensions. Turkey, the successor state, was not irredentist.

${ }^{54}$ For a very useful account of the role of elite network mobilisation in the Tajik conflict, see Idil Tuncer Kilavuz, "The Role of Networks in Tajikistan's Civil War: Network Activation and Violence Specialists," Nationalities Papers 37:5 (September 2009). I am grateful to the anonymous reviewer forpointing to this article.

${ }^{55}$ See the 2003-2010 longtitudinal data in successive Freedom House annual assessments of Nations in Transit. These show no improvement of the co-called Freedom Index in the period in question. For an analysis of political development in Georgia since 2003 arriving at the same conclusion, see S. Neil MacFarlane, Post-Revolutionary Georgia on the Edge?, Briefing Paper REP/BP/2011/01(London: Chatham House, March 2011). 